\title{
FEMALE REPRESENTATION IN BOARDS OF DIRECTORS AND ENVIRONMENTAL \\ DISCLOSURE: EVIDENCE ON THE BRAZILIAN GHG PROTOCOL PROGRAM
}

11

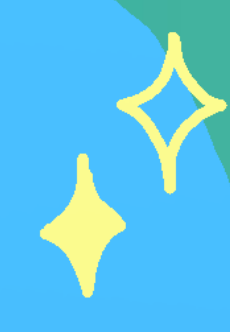

$\downarrow$

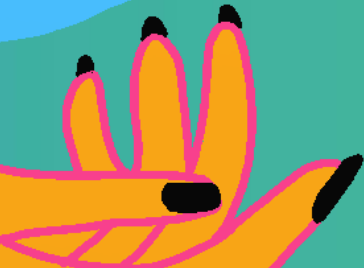

SARAH AMARAL FABRÍCIO DENIZE DEMARCHE MINATTI FERREIRA SULIANI ROVER 


\section{INTRODUCTION}

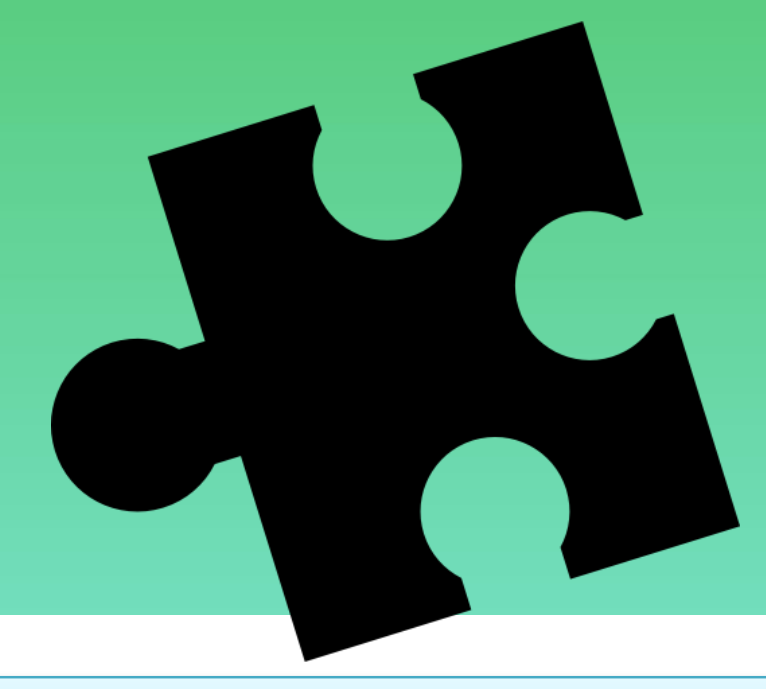

The level of GHG has been increasing in the atmosphere since the Industrial Revolution

Non-mandatory environmental disclosure in Brazil

Some Institutions and / or programs were created with the aim of controlling GHG emissions

Previous studies proved the effectiveness of women in senior management positions in environmental disclosure.

Top quality reporting from companies with women in BODs. 
The article aims to investigate the effect of female representation on boards of directors in the corporate response to the demands of voluntary disclosure of information on climate change.

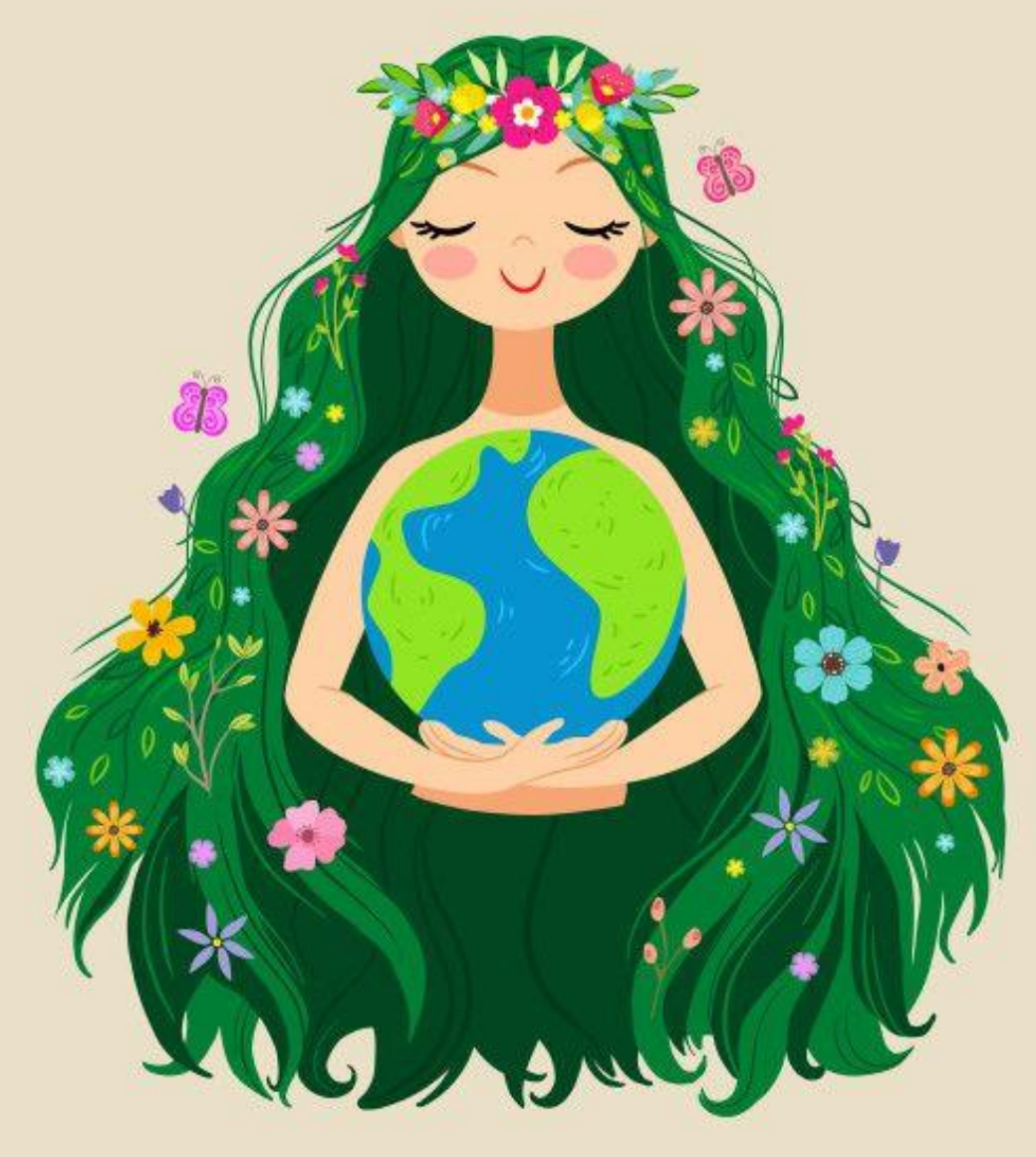


Is whether female representation on boards affects the company's decision to respond voluntarily to the demands of key stakeholders for better public reporting on GHG emission levels and risks related to climate change? 


\section{JUSTIFICATION}

- The composition of GHGs differs from water, air and is a type of dangerous pollution that can be understood as emissions of toxic chemicals, which are considered global and long-term problems with irreversible damage. (Luo, Tang, \& Lan, 2013).

- A survey of national companies shows Brazil as the seventh country with the highest emission of gases in the world, and the data analyzed from 2010 to the present point to a current scenario of stagnant emissions at approximately the same level (WRI Brasil, 2 


\section{Authors}

\section{$\frac{\sqrt{n-n}}{\sqrt{(n-5)}}$ \\ THEORETICAL FRAMEWORK}

Ben-Amar et al. (2017)

Murcia et al. (2008)

Borghei, Leung, e Guthrie (2016)

Charumathi e Rahman (2019)

Liao et al. (2015)

Lorenzo e Garcia-Sanchez (2010)

Hollindale et al. (2019)
H1: There is a positive relationship between female representation on the board of directors and the likelihood of participation in the Brazilian GHG Protocol Program. 


\section{Sample:}

- The initial sample consists of 41 companies participating in the Brazilian GHG Protocol Program from 2008 to 2018 listed on the Brazilian Stock Exchange;

- The model used is adapted from Ben-Amar et al. (2017). 


\begin{tabular}{|c|c|c|}
\hline Variable & Description & Source \\
\hline \multicolumn{3}{|c|}{ Dependent Variable } \\
\hline GHG-PROTOCOL & $\begin{array}{l}\text { Dummy variable that equals one if the firm participates } \\
\text { in the program and zero otherwise }\end{array}$ & $\begin{array}{l}\text { Brazilian GHG } \\
\text { Protocol Program }\end{array}$ \\
\hline \multicolumn{3}{|c|}{ Independent Variables } \\
\hline NB-WOMAN & Number of women seating on the board of director & $\begin{array}{l}\text { Laboratório de } \\
\text { Finanças e Risco } \\
\text { da FEA/USP data } \\
\text { base }\end{array}$ \\
\hline BLAU & \multicolumn{2}{|c|}{$\begin{array}{l}\text { Blau (1977) index of heterogeneity } H=1-\sum_{i}^{K}=I p_{i}^{2} \text {, where I number of } \\
\text { categories ( } 2 \text { for gender diversity) and pi the proportion of group members } \\
\text { (fraction of female and male directors) in each category }\end{array}$} \\
\hline $\begin{array}{l}\text { PORCENT- } \\
\text { WOMAN }\end{array}$ & Percentage of women on the board of director & $\begin{array}{l}\text { Laboratório de } \\
\text { Finanças e Risco } \\
\text { da FEA/USP data } \\
\text { base }\end{array}$ \\
\hline PRESENT-FEM & $\begin{array}{l}\text { Dummy variable that equals one if there is at least one } \\
\text { woman on the BOD and zero otherwise }\end{array}$ & $\begin{array}{l}\text { Laboratório de } \\
\text { Finanças e Risco } \\
\text { da FEA/USP data } \\
\text { base }\end{array}$ \\
\hline
\end{tabular}




\section{Control Variables}

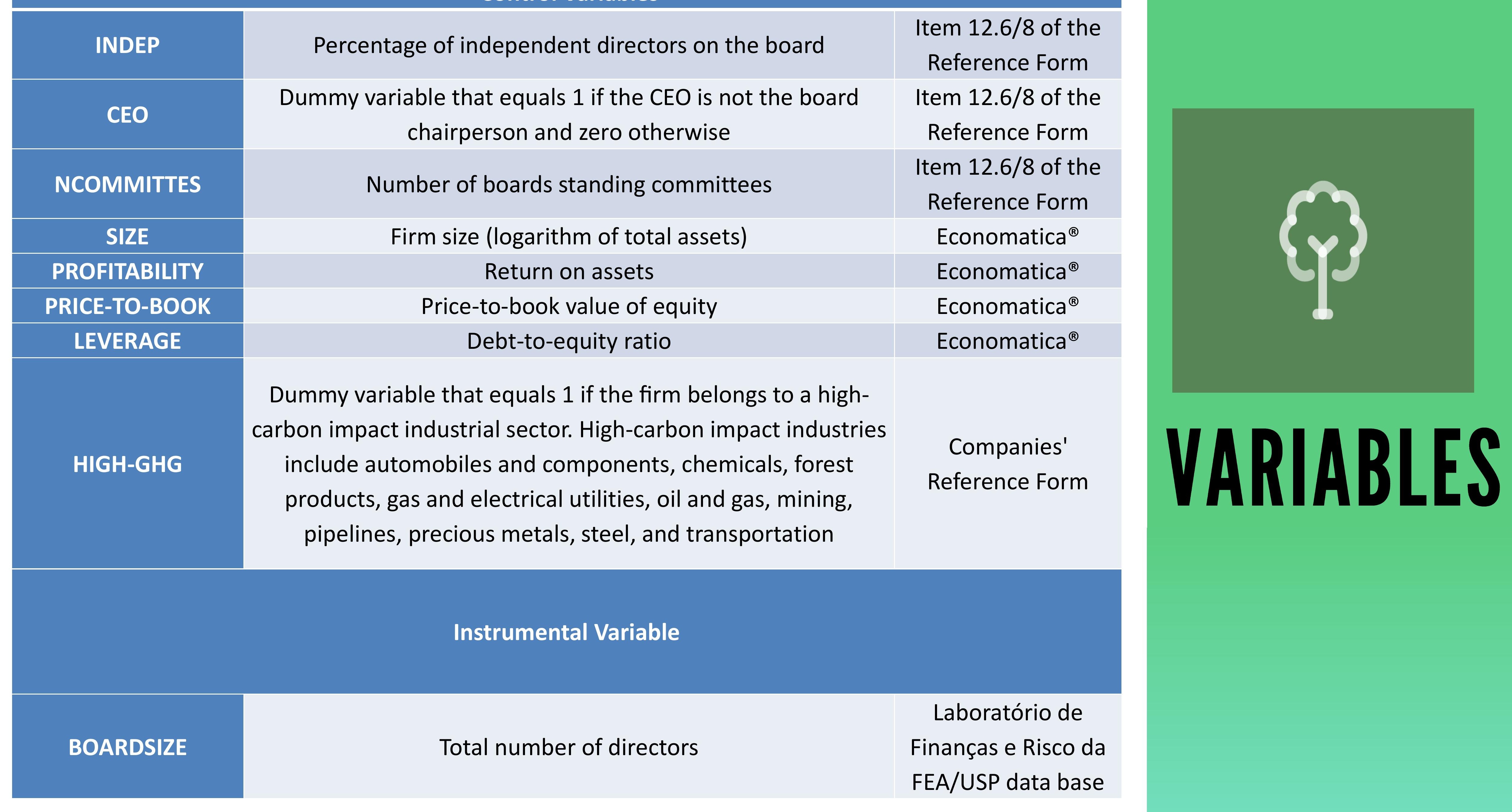


We test the following model in our multivariate analysis:

$$
P(G H G-P R O T O C O L) 1 /\left(1+e^{-g(x)}\right)
$$

Where:

$$
\begin{aligned}
& g(x) \\
& =\beta_{0}+\beta_{1} D I V E R S_{i t}+\beta_{2} I N D E P_{i t}+\beta_{3} C E O_{i t} \\
& +\beta_{4} \text { NCOMMITTES } i t+\beta_{5} \text { SIZE }_{i t} \\
& +\beta_{6} \text { PROFITABILY Yit }+\beta_{7} \text { PRICE_TO_BOOK } \\
& +\beta_{8} L E V E R A G E_{i t}+\beta_{9} H I G H-G H G_{i t} \\
& +\beta_{10} \text { BOARDSIZE } i t+\mu_{i t}
\end{aligned}
$$


- The companies participated in the Brazilian GHG Protocol Program $66.67 \%$ of the time elapsed;

- The female presence was 475 times, while the total was 4,538 men;

- The maximum number of women on the board of directors was 7, in 2017 at CCR;

- The boards had a maximum participation of $43 \%$ of women among all companies. It is also observed that there is a great disparity between the size of the councils, varying from 3 to 31 members. 


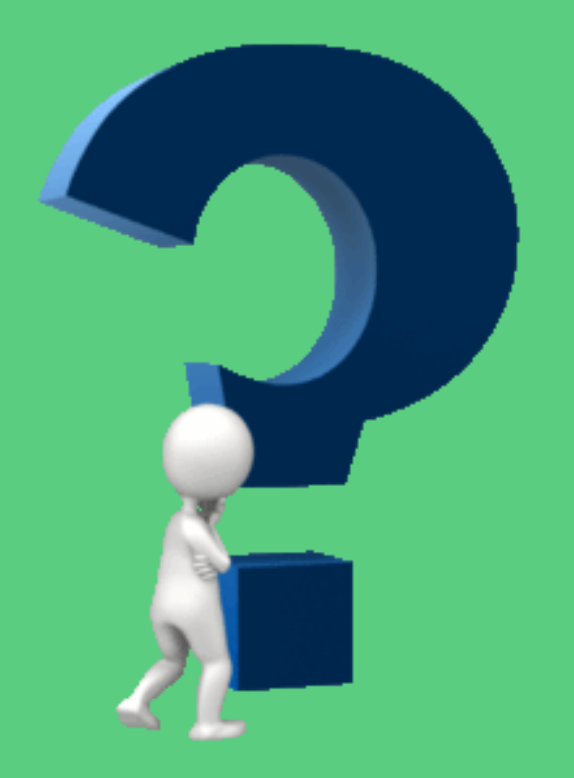

\begin{tabular}{|c|c|c|c|c|c|c|c|c|}
\hline \multirow{2}{*}{$\begin{array}{c}\text { Variable } \\
\text { GHG- } \\
\text { PROTOCOL }\end{array}$} & \multicolumn{2}{|c|}{$\begin{array}{l}\text { Blau's Index } \\
\text { Model } 1\end{array}$} & \multicolumn{2}{|c|}{$\begin{array}{l}\text { Porcent-Woman } \\
\quad \text { Model } 2\end{array}$} & \multicolumn{2}{|c|}{$\begin{array}{l}\text { Nb-Woman } \\
\text { Model } 3\end{array}$} & \multicolumn{2}{|c|}{$\begin{array}{l}\text { Present-Fem } \\
\text { Model } 4\end{array}$} \\
\hline & Coef. & Z & Coef. & Z & Coef. & Z & Coef. & Z \\
\hline BLAU & 4.67 & $3.17 * * *$ & & & & & & \\
\hline $\begin{array}{l}\text { PORCENT- } \\
\text { WOMAN }\end{array}$ & & & 6.39 & $3.01^{* * *}$ & & & & \\
\hline NB-WOMAN & & & & & 0.47 & $2.55^{* *}$ & & \\
\hline PRESENT-FEM & & & & & & & 0.57 & $1.75^{* *}$ \\
\hline INDEP & 1.17 & 0.65 & 1.03 & 0.58 & 0.83 & 0.49 & 1.12 & 0.65 \\
\hline CEO & -0.59 & -0.81 & -0.59 & -0.81 & -0.51 & -0.75 & -0.61 & -0.86 \\
\hline NCOMMITTES & -0.19 & -1.57 & -0.18 & -1.59 & -0.15 & -1.4 & -0.17 & -1.56 \\
\hline SIZE & 4.08 & $4.34^{* * *}$ & 4.03 & $4.33^{* * *}$ & 3.49 & $4.2 * * *$ & 3.75 & $4.22 * * *$ \\
\hline PROFITABILITY & 0.00 & -0.06 & 0.00 & -0.17 & -0.01 & -0.25 & -0.01 & -0.21 \\
\hline PRICETOBOOK & 0.03 & 0.47 & 0.04 & 0.56 & 0.04 & 0.64 & 0.03 & 0.54 \\
\hline LEVERAGE & -0.01 & -1.62 & -0.01 & $-1.65^{*}$ & -0.01 & $-1.68 *$ & -0.01 & -1.57 \\
\hline HIGH-GHG & -0.66 & -0.63 & -0.66 & -0.65 & -0.55 & -0.61 & -0.42 & -0.44 \\
\hline SIZEBOARD & 0.05 & 0.79 & 0.05 & 0.84 & 0.00 & -0.01 & 0.04 & 0.61 \\
\hline _cons & -28.38 & $-4.19 * * *$ & -27.94 & $-4.19 * * *$ & -23.65 & $-4.01 * * *$ & -25.68 & $-4.08^{* * *}$ \\
\hline /Insig2u & 1.98 & & 1.92 & & 1.66 & & 1.77 & \\
\hline sigma_u & 2.69 & & 2.61 & & 2.29 & & 2.42 & \\
\hline rho & 0.69 & & 0.68 & & 0.61 & & 0.64 & \\
\hline
\end{tabular}


- The results do not reject $\mathbf{H 1}$, in all the statistical models used.

- When using Blau Index and female presence dummy variable models there are a positive and significant relationship with the size of the companies;

- And using female percentage variable in the councils and the variable of the number of women there are a positive and significant relationship with the size of the companies and with the leverage of the companies;

- These results corroborate the results of Liao et al. (2015) and Ben-Amar et al. (2017) and as in the models previously tested, suggest that the participation of women in the councils contributes to a greater probability of companies joining or continuing in GHG reduction programs. 


\section{CONCLUSION}

- Our results corroborate research that points to a positive effect of gender diversity in the adoption of corporate social responsibility practices (Ben-Amar et al., 2017; Hollindale, Kent, Routledge, \& Chapple, 2019; Prado-Lorenzo \& Garcia-Sanchez, 2010; Zhang, Zhu, \& Ding, 2013) and the quality of the financial reports (Gul, Srinidhi, \& Ng, 2011).

- With these results, it is expected to take the research a step further in the quest to contribute to the fight against global warming and encourage diversity in the boards. 


\section{CONCLUSION}

- This research presents the limitation of the Brazilian GHG Protocol Program to present a low number of companies listed on the Brazilian Stock Exchange, since the year in which most companies participating in the publicly traded program was in 2018, with 42 companies, which it can reduce the impact of these findings in relation to countries where there is a greater number of companies that have joined this type of program.

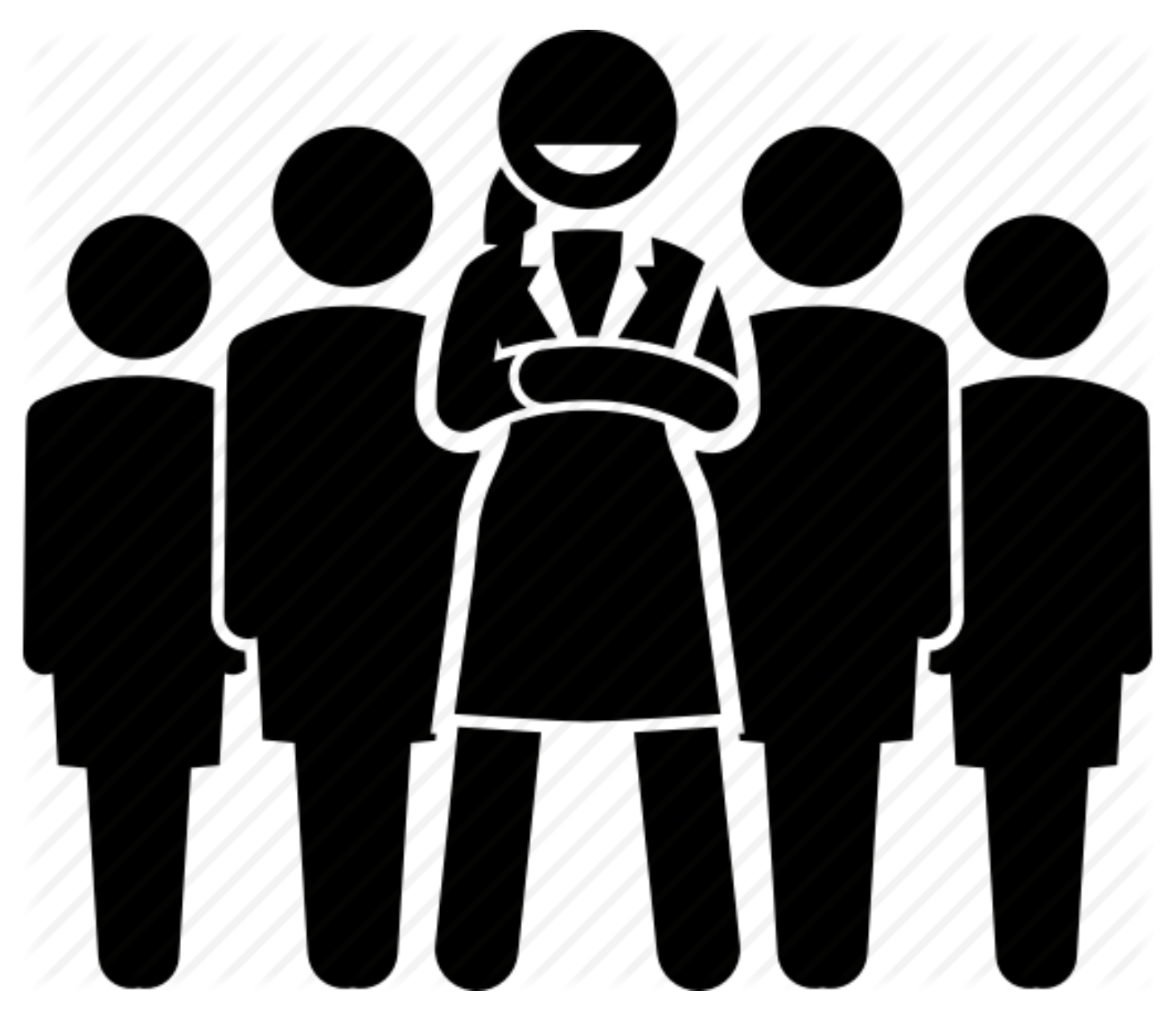




\section{FEMALE REPRESENTATION IN BOARDS OF DIRECTORS AND ENVIRONMENTAL}

\section{DISClosure: EVIDENCE ON the brazILIAN ghi protocol program}

\section{Obrigada! Thank you!}

SARAH AMARAL FABRÍCIO * DENIZE DEMARCHE MINATTI FERREIRA * SULIANI ROVER 